\title{
A study on Career Adaptation of Career Interrupted Women Using National Competency Standard Career Development Education
}

\author{
Im-Sun Park ${ }^{1}$, Mi-Na Lee ${ }^{2}$, Dong Il Kim ${ }^{3}$ \\ ${ }^{1}$ The Doctor's Course, Department of Human Service Education, Kwangshin University, \\ South Korea,wotodfks@hanmail.net \\ ${ }^{2}$ Professor, Welfare Counseling Convergence Department, Kwangshin University, South Korea, \\ Imn4780@naver.com \\ ${ }^{3}$ Visiting Professor, Faculty of Welfare Counseling Convergence, Kwangshin University, South \\ Korea, ks04014@hanmail.net
}

Corresponding author: Mi-Na Lee

\begin{abstract}
This study is intended to examine the effectiveness of career adaptability using National Competency Standards (NCS) a career development education to career interrupted women. The subjects are 30 women who have experienced career disruption at the Lifetime Learning Center located in N City, Jeollanam-do., divided into experimental and control groups. To determine the statistical significance of the research problems set out in this study, SPSS WIN 23.0 was used, and the statistical analysis method is specifically described as follows. The NCS career development education program consists of the process of introduction, development, progression, and completion, and specifically, it consists of meeting, what would they like to do, and self-understanding for career development, world, and career design. Career development education programs need to be planned and operated as a way to enhance career adaptability for career interrupted women. Currently, there are career programs operated by the Ministry of Employment and Labor and vocational schools, but career development education at the level of lifelong education for career adaptation should be operated. Therefore, this study suggests that it is necessary to support career interrupted women to form employment and startup clubs without giving up on re-entry into the labor market, create volunteer activities and career conversion opportunities, and continuous research on using NCS learning modules that can easily apply for standardized career education programs. It is believed that more in-depth research on the use of NCS learning modules to facilitate the application of standardized career education programs is needed to help career interruption women create career opportunities.
\end{abstract}

Keywords: Career Interrupted Women, NCS, Career, Vocational Training, Lifelong Education, Adaptation

\section{Introduction}

The Fourth Industrial Revolution emphasizes the need and direction of innovation and change in vocational education. The pandemic, which hit the world in 2020, is a factor driving the pace of this change. Existing jobs are disappearing while new jobs, high-value-added industries, and convergence

Received: July 22, 2021; $1^{\text {st }}$ Review Result: September 09, 2021; $2^{\text {nd }}$ Review Result: October 22, 2021 Accepted: November 30, 2021 
jobs are emerging. This marks a turning point in society's life-long career, not a lifelong job. As society changes from labor-intensive industries to expertise-oriented industries, or knowledge-based industries it will be necessary to develop vocational skills at any point in life beyond the existing level of schooling. It is also necessary to provide lifelong education opportunities for career interrupted women who can work with expertise to enter the productive population group[1].

According to data from the National Statistical Office in 2017, a career interrupted women quit their jobs in the order of marriage (34.5\%), childcare (32.1\%), pregnancy and childbirth $(24.9 \%)$, family care (4.4\%), and child education (4.1\%). Recently, the level of education between men and women has little difference, and the demand for women's participation in economic activities has been on the rise[2]. Therefore, there is a need for discussion with the non-economic participation population, not the women's own choice. In March 2017, some amendments to the Act on Promotion of Economic Activities of Career Disconnected Women and others passed the plenary session. The Act allowed reemployment support for career interrupted women and preventive services to help women continue their economic activities without career interruption. This is expected to help boost women's participation in economic activities. However, even if the government provides systematic support, its efficiency will not be guaranteed unless the psychological and emotional aspects of the experience are taken into account during the career break. Career-breaking women should also find happiness and satisfaction to overcome career-breaking, and expand their areas of life and encourage active social activities[1].

A career-breaking woman is a woman who experienced career interruption when she returned to society with her child's growth. They can experience frustration again and encounter the reality that is difficult to demonstrate their ability as a human resource. Recently, however, a career interrupted women who dream of resuming their social activities are increasingly trying to improve their lives through lifelong learning. This is because there are more opportunities due to the expansion of lifelong education, and there are more opportunities to develop professionalism such as obtaining degrees or certificates through lifelong learning[2].

In modern society, many people do not think that completing a regular curriculum has ended their learning needs. The rapidly changing social environment of the 21 st century, represented by the average life expectancy of humans, increased leisure time, advances in science and technology, and changes in job structure, has dramatically increased adult learners' learning needs and naturally emphasized the importance of lifelong learning society. In particular, practical education using National Competency Standards (NCS), which focuses more on skills than jobs, is expanding based on field-based talent development, and the need for a one-time, one-learning, and qualifying NCS-based vocational curriculum has been continuously raised. As a result, Korea began developing the National Occupational Competency Standards (NCS) in 2002 based on various abilities of all professionals and recently announced 12,405 competency units for a total of 1,001 jobs in June 2019. As such, NCS development, improvement, and utilization are continuously promoted by related departments to expand NCS utilization, including development and distribution of NCS-based vocational training courses, reorganization and application of qualifications, and recruitment. This appears to complement difficulties in applying NCS in earnest.

Lee Yong-hee[3] said that in the NCS-based vocational competency education direction study, it is urgent to develop guidelines for the connection and utilization of NCS competency units, including the establishment of work and qualification. This suggests that it is time for lifelong education and vocational ability to change as the NCS continues to develop and improve. In other words, it can be seen that NCS at the national level, which aims to reform from a school-centered society to an ability-oriented society, is seeking to establish lifelong education[4].

In addition, the desire to re-employment of a career interrupted women shows that the younger the age group, the higher the educational background, the greater the meaning of self-improvement, not just economic issues such as living and child education[5]. The purpose of reemployment for career-breaking 
women is self-realization, economic fulfillment, and social engagement[6]. Self-realization was the highest desire for reemployment[7]. Nam Ki-sook[8] confirmed that self-realization was the highest reason why highly educated women wanted re-employment, and that they considered aptitude and majors. It analyzed domestic research trends on women's career barriers and revealed that they are divided into personal factors and social relationship context studies. Similar studies include career preparatory behavior and relationships with career aspirations for married women, social support for unemployed women and the level of career decision[9-11].

In a study on the coping arrangements required for reemployment success for career-disconnected women, a conceptual diagram of job selection was derived considering job preparation behavior, family role coordination and work-family compatibility[12]. Employment preparation can be done through the use of informal sources such as people or institutions that provide hidden employment information through employees, family members, friends, relatives, in the company who wish to get a job[13]. In addition, the use of networking and informal information was seen as an effective way to find a new job. In a qualitative study on the reentry of career-breaking women into the labor market, highly educated women also obtained the information necessary for employment with workers in the field of reemployment and studied their successful reemployment through the perception of reality in the labor market[8].

Recently, career adaptability is an important factor in the career field. Super and Knasel[13] called career adaptability a readiness to cope with changing situations and job conditions, while Savickas[14] defined career adaptations based on the degree to which he can prepare for reemployment and how he can prepare for changes. Goodman[15] focused on the balance sought by individuals between the world and the environment of work, explaining predictable challenges in preparing and participating in occupational roles, and preparation for unpredictable adaptation problems[16]. Career adaptability is a psychological and behavior factor in a career interrupted women's reemployment success[12]. Careerdisconnected women said that emotional education to overcome psychological difficulties during the career-disconnected period was lacking through re-education, and that they should get a chance to change their lives to promote sociality and relationship[2].

For career interrupted women to change their career, they need to grow their inner strength in personal, social, and environmental situations to prepare for their careers. This needs to improve career adaptability against environmental changes in the labor market[5]. In this study, career-breaking women sought to improve career adaptability by utilizing NCS-based career development education programs to prepare for reemployment. The research questions in this study are as follows:

First, what are the effects of a career adaptability using NCS career development education to career interrupted women? Second, is NCS-based career development education for career interrupted women effective in career adaptation?

\section{Theoretical Background}

\subsection{Career-disconnected Women}

Experience refers to the various experiences that an individual experiences throughout his or her career or work. Women's economic activities are discontinuous due to the relatively greater impact of life events such as marriage, childbirth and childcare than men's, and often shift from employment to non-economic activities[17]. Kim In-sun[18] considered career-disconnected women to be disconnected due to life-history events such as marriage, pregnancy, childbirth and parenting, but recently, many external factors such as changes in the social environment, job shortages, and reduction of organizational staff led to economic disruption. Education and job policies supported by career-breaking women should be expanded to a culture where companies and countries work together to provide professional education 
and training so that they are linked to work-family compatibility and high-quality jobs. In addition, career-breaking women have the characteristics of experiencing changes in their economic activities over the life cycle. This characteristic can be interpreted as the cause of employment disruption in careerbroken women, such as marriage, childbirth and parenting[19]. Career disruption was used in 2002[20] and was used as a career-disconnector woman in a state of being separated from a viable economic career by any external or internal factors.

In this study, according to the definition of the Act on Promotion of Economic Activities of CareerDiscontinued Women (2017), they are the women who wish to get a job who have been stopped or have never done economic activity (Article 2.1 of the Career-Discontinued Women Act, 2017). In other words, we want to include women who want to get out of this disconnected state and get a job again through this life process.

\subsection{Career Disconnected Women's Career Adaptability}

Career adaptability is suggested at the limitation of the concept of career maturity in explaining career development in adults. Super and Knasel[13] interviewed field workers aged 18-35 at the request of the Canadian Employment and Immigration Service to develop and implement a career maturity model for adults. In this process, learning that the content and level of career-related development tasks are bound to vary because adult career development is influenced by various social roles and contexts. In other words, it was discovered that the concept of career maturity was not appropriate for adults and proposed career adaptability as an alternative concept.

Career maturity originated from the anthropogenic form of biology and has a pattern common to career development. As people get older, there are continuous courses in career-related competencies and attitudes, and the development tasks to deal with differ depending on age[21]. Super[22], published career-level theories and presented development tasks to be completed at each stage, which can be conceptualized in a single direction. Career maturity was used in adolescents ahead of career decisionmaking to determine what level of career-related internal growth compared to their age and development stage[23]. However, the stages of growth, exploration, establishment, maintenance and retirement are straightforward, and when faced with unexpected problems as a continuous development process, they argued for career adaptability for adults[15].

Career adaptability has expanded to a concept that is available to all age groups where role transitions are expected in addition to adult workers. He explained that one of the most representative environmental changes in the working-related domain is social role changes. This argued for career adaptability to change the key for social roles, requiring re-adjustment of roles for new lives, abandoning old roles and adopting new ones, or modifying existing ones[23]. On the other hand, it is necessary to extend career adaptability to concepts that include not only aligning oneself with external environmental changes and needs but also changing the environment or situation in line with individual changes[24]. Thus, with the importance of how individuals will flexibly respond to changes in their careers and how to manage their careers in rapidly changing social changes, career adaptability emphasizing the environmental context and individual interaction is discussed in a variety of ways[25].

Career adaptability is the ability of an individual to adapt to the needs of a job[23], preparation to cope with changing work and work conditions, preparation to cope with foreseeable tasks[14], occupational development tasks, occupational transitions, and successful career transitions[26]. This can be said to mean that career adaptability includes the ability to change or adapt, the attitude to cope with change, and proactive career behavior[21]. Prior studies on career adaptability include the development of career adaptability measures for college students as well as adults[27], and the preparatory studies required for reemployment as factors for career-breaking women[9]. It is expanding into concepts that can be applied to various ages and subjects. career interrupted women's career adaptability includes the 
preparation and attitude of career actions for a successful career transition from social changes.

\subsection{Life Cycle and Career Choices}

Career is used to include not only economic activities but also non-economic activities such as housework and social service. In other words, it is a collective term for what humans do throughout their lives, and a career path is also a way for humans to achieve their goals. Career is not limited to paid jobs but includes all work activities that begin in childhood and continue after retirement from work as an adult. Other activities can construct individual careers, including education, occupation, home, family and community services[27]. However, this study aims to focus on career-related careers.

In the past, career development-related theories have been discussed mainly men's career development, but recently, there has been a lack of consideration on women's career development.

Super's career development theory is considered to have lifelong educational implications, including the stages of career development throughout the entire life[28]. Nevertheless, it is necessary to consider the stage of career development for women who are likely to experience occupational career disruption due to childbirth and childcare and to lose professional stability. In addition, the established and maintained periods, which included the middle-aged period in the course development phase, were considered to be a fairly stable period of adaptation. For example, the establishment period of career development between 25 and 45 years old is a period of stabilization, strengthening status, and professional progress in the chosen occupational area. For women, however, due to career disruption due to childbirth and parenting, and the desire to redefine the post-child life structure, the middle-aged period is considered to be a new explorer or a period of confusion[13].

Through the analysis of employment skills for ten years after the first childbirth, it was revealed that women's employment paths were dynamic and diverse, raising the question of how they divided into "economic activity-oriented women" and "family-oriented women[29][30]". It is also said that middleaged individuals experience a wide variety of life developments[31] so women need to explore new careers at any point in their lives and develop career and vocational education to actively seek new careers at any age[29]. On the other hand, career-related women's career choices can be identified and visualized, and individual women's career choices can be also more responsive to obstacles. Disability factors for women's career choices were presented separately between environmental and personal disabilities[32]. These disorders are said to tend to elicit gender stereotypes and traditionally feminine choices, including gender role stereotypes, occupational stereotypes, gender bias in education, disabilities in higher education, lack of role models, gender-biased career counseling, racism, and expectations of career conflict and success[32]. A case study of 12 adult women at different stages of life cycles in their 20s and 40s extracts employment promotion factors and inhibitors according to life cycle characteristics[33]. According to the results of the life-cycle study, first, women in the first stage of life-cycle (20-24) have job promotion factors that fit their needs through steady preparation, a womanfriendly working environment, understanding of marriage, and self-identification of working identity. On the other hand, factors that hinder employment include the environment of the sexual role and lack of women's understanding of works and job links. Second, women in the second phase of their life cycle ( 25 to 34 years old) have positive role models for working women, the importance of women's economic independence, and a woman-friendly workplace environment. On the other hand, factors that hinder employment include stereotypes of gender roles, the absence of maternal protection for childbirth, malecentered family systems, and the internalization of sacrificial femininity. Factors that promote employment for women in the third phase of their life cycle (35 years of age or older) include a firm sense of occupation to lead their own lives through economic independence, continuous job search and job preparation, and reemployment experience. The factors limiting employment were the closed labor market, downward reemployment experience, long experience of job disconnection, lack of confidence 
due to rapid technological changes in the labor process, lack of adaptability, and stereotypes of traditional gender roles. This means that the professional career disconnection aspect of women's career choices has not been ostensibly revealed and has not been socially issued in the male-centered career selection theories.

\subsection{NCS-based Programs}

The focus of this study is on proving the effectiveness of NCS-based programs for career-interrupted women. Lifetime education can provide customized programs for adult learners to support the rapidly changing labor market and the various demands of vocational education due to the development of technology, and can be conducted as regular and irregular educational activities in connection with local communities.

Lifetime education is an education that contributes to improving job accessibility and the value and utility of human resources by preparing effective educational alternatives to the common parts of the education and labor market. The introduction of NCS-based lifelong vocational education courses in research on the direction of lifelong vocational education based on national vocational competence standards does not presuppose that the 'division' of education developing lifelong vocational education courses using the industry-developed NCS[34]. Therefore, NCS should be a medium for promoting close links between education and industry, and a variety of systems or training systems based on NCS should be organically constructed based on links between industry and education. In addition, the NCSbased lifelong vocational education course minimizes the gap between lifelong vocational education and industrial demand through NCS. To this end, professors' expertise, teaching and learning capabilities, experimental and practical conditions, industrial-academic infrastructure, and flexible Bachelor's operating system should be strengthened. This needs to be extended to discussions on how the workforce training system in lifelong education should be improved based on NCS rather than limited discussions on improvements to individual components. In a study on the improvement of career basic skills of learners in NCS-based lifelong education, job competency development factors can have a positive impact on communication improvement when the education system and curriculum are harmonized[35][36].

Until now, most lifelong education institutions have found it difficult to actively intervene in operating an NCS-based curriculum, and related research is insufficient. If the standardized curriculum is applied and its effectiveness is verified, it can be actively used for vocational education, career education, and learner-tailored education as lifelong education programs.

\section{Study Method}

The NCS career development education program consists of the process of introduction, development, progression, and completion, and specifically, it consists of meeting, what would they like to do, and self-understanding for career development, world, and career design. Career development education programs need to be planned and operated as a way to enhance career adaptability for career interrupted women.

\subsection{Research Subjects}

The subject of this study is 30 women with disconnected careers in a lifelong learning center located in $\mathrm{N}$ city, Jeollanam-do. The career development education program was conducted from March 10 , 2020, to November 20, 2020, once a week for 30 weeks, every 120 minutes. and The program was conducted by a professional instructor with related educational experience and counseling experience. 
The purpose of the study was explained to the subjects, the consent of the study participants was obtained, and the program was carried out. This study selected research participants using a purposeful sampling to apply for career development education programs by following per under the National Occupational Competency Standards (NCS). At the site where the in-depth consultation was conducted, a brief introduction and questioning on the subjects of the study were conducted to form Rapport. In particular, participants were briefed on the NCS and interviews were recorded and stored with consent, and during the interview, researchers conducted in-depth questioning while recording important keywords.

\subsection{Research Tools}

As a measurement tool for career adaptability in this study, the tool utilized by Cho Eun-joo[37], which was a draft and reconstruction of the Career Futures Inventory-Revised (CFI-R) revised by Rottinghaus et al.[36] was used. The CFI-R revision consists of five sub-factors: Career Agency, Negative Career Outlook, Occupational Awareness, Support System, and Work and Life Balance. CFI$\mathrm{R}$ is a measurement tool consisting of 28 questions revised by Rottinghaus et al. (2012) and is expected to respond on a Likert 5-point scale from "very yes" to "not at all". The overall reliability Cronbach a coefficient for CFI-R tests was .94. The composition and reliability of the measurement tools are presented as shown in [Table 1].

[Table 1] Career Adaptability Composition and Reliability

\begin{tabular}{cccc}
\hline Subtype & Number & Quesion & Cronbach a \\
\hline Career subjectivity & $1,2,3,4,5,6,7,8,9,10$ & 10 & .927 \\
\hline Negative career prospects & $11^{*}, 12^{*}, 13^{*}, 14 *$ & 4 & .737 \\
\hline Occupational awareness & $15,16,17,18,19,20$ & 6 & .890 \\
\hline Support system & $21,22,23,24$ & 4 & .911 \\
\hline Working and life balance & $25,26,27,28$ & 4 & .940 \\
\hline
\end{tabular}

* This is a reverse grading question

\subsection{Data Analysis}

To determine the statistical significance of the research problems set out in this study, SPSS WIN 23.0 was used, and the statistical analysis method is specifically described as follows: First, the reliability of the measurement tool was verified by calculating the Cronbach a coefficient. Second, to verify the effectiveness of the program, a response sample $t$ was tested for differences between the prior and postcareer adaptability.

\subsection{Program Contents}

The contents of the program conducted in this study are as shown in [Table 2]. 
[Table 2] Career Development Education Program on NCS-based

\begin{tabular}{|c|c|c|}
\hline & Subject & Program \\
\hline 1 & \multirow{2}{*}{$\begin{array}{l}\text { Meeting and } \\
\text { Exploring what I want to do }\end{array}$} & $\begin{array}{l}\cdot \text { Lapo formation, creating expectations for } \\
\text { the entire process } \\
\text { - Learn your needs for a career }\end{array}$ \\
\hline 2 & & $\begin{array}{l}\text { - Empathy and listening training for dialogue } \\
\text { - Nonviolent dialogue to improve relationships } \\
\text { - Training to find feelings and desires }\end{array}$ \\
\hline 3 & \multirow{3}{*}{$\begin{array}{l}\text { Self-understanding for career } \\
\text { development }\end{array}$} & $\begin{array}{l}\text { - Understanding career path } \\
\text { - Explore career interests and personality } \\
\text { - Find interest }\end{array}$ \\
\hline 4 & & $\begin{array}{l}\text { - Who am I? } \\
\text { - My strength talent } \\
\text { - Find what you want to do inside of me }\end{array}$ \\
\hline 5 & & $\begin{array}{l}\text { - Explore personality types } \\
\text { - Find resources through SWOT analysis } \\
\text { - Career according to personality type }\end{array}$ \\
\hline 6 & \multirow{3}{*}{$\begin{array}{l}\text { For career development } \\
\text { professional } \\
\text { understanding }\end{array}$} & $\begin{array}{l}\text {-What is a job? Diversity of occupation and necessity of occupation } \\
\text { - Exploring jobs using job cards } \\
\text { - Occupational value and work ethic }\end{array}$ \\
\hline 7 & & $\begin{array}{l}\text { - Understanding job changes during the Fourth Industrial Revolution } \\
\text { - UN } 2030 \text { Future Job (Virtual Reality/3D Printer/Drone/Artificial } \\
\text { Intelligence/Internet of Things) }\end{array}$ \\
\hline 8 & & $\begin{array}{l}\text { - Experience in the workplace } \\
\text { - A job recognized by feet } \\
\text { - Create an experience report }\end{array}$ \\
\hline 9 & \multirow{2}{*}{$\begin{array}{l}\text { Career design for career } \\
\text { development }\end{array}$} & $\begin{array}{l}\text { - Job in future society } \\
\text { - Entrepreneurship and start-up } \\
\text { - Creativity strategies for discovering startup items }\end{array}$ \\
\hline 10 & & $\begin{array}{l}\text { - I'm a CEO } \\
\text { - Life game using story talking } \\
\text { - What is a meaningful life? } \\
\text { - My } 4 \text { Future images }\end{array}$ \\
\hline
\end{tabular}

\section{Results}

The results of the t-verification overall response sample of career adaptability between groups to examine the pre-and post-score scores of experimental and statistical groups on career adaptability are as shown in [Table 3].

[Table 3] Overall Career Adaptability Response Sample Results

\begin{tabular}{l|l|l|l|l|l}
\hline \multirow{2}{*}{ Group } & \multicolumn{2}{l}{ Post } & Pe & \multirow{2}{*}{$\mathrm{t}$} \\
\cline { 2 - 6 } & $\mathrm{M}$ & $\mathrm{SD}$ & $\mathrm{M}$ & $\mathrm{SD}$ & \\
\hline Experiment & 2.5060 & .51346 & 4.0643 & .12632 & $-15.260^{* * *}$ \\
\hline Control & 2.4440 & .64495 & 2.7619 & .34363 & -2.614 \\
\hline
\end{tabular}

$* * * \mathrm{p}<.001$

The results of pre- and post-test shall as shown in [Table 4], identified the effects of each subfactor of 
career adaptability.

[Table 4] Sample Results of Path Adaptability between Groups by Subfactor

\begin{tabular}{|c|c|c|c|c|c|c|}
\hline Sortation & Group & $\begin{array}{l}\text { Post } \\
\text { M }\end{array}$ & SD & $\begin{array}{l}\text { pre } \\
\mathrm{M}\end{array}$ & SD & $\mathrm{t}$ \\
\hline \multirow{2}{*}{ Career identity } & Experiment & 2.2867 & .74821 & 4.5667 & .20899 & $15.195 * * *$ \\
\hline & Control & 2.2033 & .40555 & 2.9067 & .50236 & 7.214 \\
\hline \multirow{2}{*}{$\begin{array}{l}\text { Negative career } \\
\text { prospects }\end{array}$} & Experiment & 3.4750 & .75530 & 1.6333 & .27647 & $-12.362 * * *$ \\
\hline & Control & 3.5250 & .80234 & 3.0833 & .64438 & -2.563 \\
\hline \multirow{2}{*}{$\begin{array}{l}\text { Occupational } \\
\text { awareness }\end{array}$} & Experiment & 2.2389 & .75770 & 4.5000 & .19078 & $15.263 * * *$ \\
\hline & Control & 2.0500 & .67545 & 2.6944 & .52172 & 5.356 \\
\hline \multirow{2}{*}{ Support system } & Experiment & 2.4750 & .68967 & 4.2917 & .27136 & $12.503 * * *$ \\
\hline & Control & 2.2500 & .71318 & 2.4833 & .71599 & 3.500 \\
\hline \multirow{2}{*}{$\begin{array}{l}\text { Working and life } \\
\text { balance }\end{array}$} & Experiment & 2.5167 & .76545 & 4.3583 & .23382 & $11.501^{* * *}$ \\
\hline & Control & 2.6500 & .44334 & 2.4583 & 64019 & 1.791 \\
\hline
\end{tabular}

$* * * \mathrm{p}<.001$

As shown in [Table 4], the results of t-validation of intergroup path adaptability response samples are as follows: The results of verification on career identity, negative career prospects, job awareness, support system, and work-life balance are sub-factors of career adaptability. Career subjectivity was 4.56 points for the experimental group and 2.90 points for the control group. The difference between groups is statistical $(\mathrm{t}=15.195, \mathrm{p}<.001)$ indicating a significant differences. In other words, the experimental group has improved identity compared to the control group.

According to the negative career outlook, the experimental group scored 1.63 points and the control group 3.08. The difference between groups is statistical $(\mathrm{t}=15.195, \mathrm{p}<.001)$ indicating significant differences. In other words, the experimental group showed fewer negative career prospects compared to the control group. According to occupational recognition, the experimental group scored 4.50 and the control group 2.69. The differences between these groups are statistical $(\mathrm{t}=15.263, \mathrm{p}<.001)$ indicating the significant differences. In other words, the experimental group has improved job recognition compared to the control group. According to the support system, the experimental group scored 4.50 points and the control group 2.69 The differences between these groups are statistical $(t=11.501, p<.001)$ indicated significant differences. In other words, the experimental group showed an improved support system compared to the control group.

In terms of the working and life balance, the experimental group scored 4.35 and the control group 2.45. The differences between these groups are statistical $(\mathrm{t}=11.501, \mathrm{p}<.001)$ indicated a significant differences. In other words, the experimental group showed an improved working and life balance over control.

\section{Conclusion}

This study was conducted to understand the effectiveness of NCS-based career development education programs for career interrupted women. The subjects of the study are 30 people from experimental and control groups who participate in NCS-based career development education for 
learners at the Lifetime Learning Center located in N-City, Jeollanam-do. The method of selecting the target was to identify women in their 20s and 50s who wish to participate in lifelong education programs for employment by N-city and to introduce the contents and purpose of this program. Participants who agreed to participate in the program participated in the 10th period program, participated in the NCSbased career development education program and examined the effects of career adaptability before and after the program.

The description of the program was conducted on the experimental group and the control group for career adaptability, and the intergroup homogeneity test was conducted in advance. The career development education program was conducted once a week for 30 weeks, 120 minutes each, and the program was conducted by a professional instructor with related educational experience and counseling experience. The measurement result data analysis method used the SPSS window 21 programs and frequency analysis, and response sample t-test was conducted to verify research problems.

Career adaptation was consistent with Ahn's study that career-breaking women's self-esteem affects their career, and positive self-conceptions of a career interrupted women also had a positive impact on career preparation. In the life cycle characteristics and multiple roles of women considered in previous studies, career interrupted women need to support each other through sharing knowledge with program participants to enable career adaptability and social support systems.

As such, career interrupted women should expand into a culture where companies and countries work together to provide professional education and training so that education and job policies are linked to work and family compatibility and quality jobs. Career development education programs need to be planned and operated as a way to enhance career adaptability for career-breaking women. Currently, there are career programs operated by the Ministry of Employment and Labor and vocational schools, but career development education centered on self-understanding education should be operated and reviewed, find abilities, increase positive self-esteem, and explore information about changes in the labor market to think about what they should prepare for.

This needs to be extended to discussions on how the workforce training system in lifelong education should be improved based on NCS rather than limited discussions on improvements to individual components. In a study on the improvement of career basic skills of learners in NCS-based lifelong education, job competency development factors can have a positive impact on communication improvement when the education system and curriculum are harmonized.

Career interrupted women should be able to form employment and start-up clubs without giving up on re-entry into the labor market, and volunteer meaningful activities should be continued through linked activities with local communities. It is a more in-depth research on the use of NCS learning modules to facilitate the application of standardized career education programs is needed to help career interrupted women create career opportunities. The limitation of this study is that it is a case conducted in one region, so there is a limit to generalization. There is a need to study more regions. In addition, the study was conducted only on women with career interruptions, but a study on men with career interruptions is needed in the future.

\section{Reference}

[1] E. Y. Jung, A study on the perception change through lifelong learning of career-interrupted women: Focusing on the participants in the image coaching program, Baekseok University, Doctoral Dissertation, (2018)

[2] D. H. Lim, Analysis of the effects of reemployment policies for women with career interruption. Focusing on the analysis of differences between vocational education and training and group types, Sungkyunkwan University, Doctoral Dissertation, (2017) 
[3] Y. H. Lee, A study on the effect of NCS-based curriculum design on educational performance, Soongsil University, Doctoral Dissertation, (2016)

[4] H. H. Kim, Lifelong Education Program for Adult Female Learners: Focusing on Women's Human Resources Development Center, Chung-Ang University, Master Thesis, (2011)

[5] N. K. Kim, The effects of self-esteem, self-determination, and social network on career adaptability of careerinterrupted women, Soongsil University, Doctoral Dissertation, (2017)

[6] E. J. Joe, The effect of social support program for adult learners on career adaptability and self-concept, Soongsil University, Doctoral Dissertation, (2015)

[7] K. H. Kim, H. J. Kim, The relationship between character of participation in lifelong education and social capital of the Aged, Korean Journal of Social Welfare Education, (2016), Vol.33, pp.29-57, UCI: G704-SER000010583. 2016.33..001

[8] M. S. Nam, Analysis of the effects of participation in lifelong education programs for women with career interruption with high education, Duksung Women's University, Master Thesis, (2012)

[9] M. K. Hong, The effect of career-interrupted women's lifelong learning participation motivation on employability and the mediating effect of career design, Baekseok University, Doctoral Dissertation, (2017)

[10] S. O. Seo, Structural analysis of lifelong learning participation and structure of married female learners, Mediating effects of career development preparation, Dong-A University, Doctoral Dissertation, (2013)

[11] A. H. Kim, A narrative exploration on career transition experiences of women with career interruption, Dankook University, Doctoral Dissertation, (2017)

[12] Korean Education Development Institute, 2017 Educational statistics analysis data book: Lifelong education statistics side, Korean Education Development Institute, (2017)

[13] D. E. Super, E. G. Knasel, Career development in adulthood: Some theoretical problems and a possible solution, British Journal of Guidance \& Counseling, (1981), Vol.9, No.2, pp.194-201, DOI: https://doi.org/10.1080/ 03069888100760211

[14] M. L Savickas, Career Adaptability: An integrative construct for life-span, life-space theory, The Career Development Quarterly, (2011), Vol.45, No.3, pp.247-259, DOI: https://doi.org/10.1002/j.2161-0045.1997.tb00469.x

[15] J. Goodman, Career adaptability in adults: A construct whose time has come, The Career Development Quarterly, (1994), Vol.43, No.1, pp.74-84, DOI: https://doi.org/10.1002/j.2161-0045.1994.tb00848.x

[16] M. S. Jung, H. S. Lee, The Effects of Participation Motivation for Vocational Education Program of Middle-aged Female Learners' on Participation Continuation Intention and Mediating Effects of Educational Satisfaction, Journal of Lifelong Learning Society, (2017), Vol.13, No.2, pp.109-133, DOI: https://doi.org/10.26857/JLLS.2017.05.13.2.109

[17] J. H. Ryung, Critically Exploring Social Capital in Lifelong Education, Journal of Lifelong Education, (2009), Vol.15, No.2, pp.53-75, UCI: G704-000781.2009.15.2.004

[18] J. M. Kang, D. O. Park, The Adult Learner's Motivation and Educational Satisfaction Effect on Social Formation, The Journal of Education Assignment Institute, (2017), Vol.23, No.1, pp.1-20.

[19] K. A. Lee, Study on Empirical Relations Between Social Capital and Lifelong Education, Journal of Lifelong Education, (2008), Vol.14, No.2, pp.117-146, UCI: G704-000781.2008.14.2.005

[20] R. Y. Moon, A grounded theoretical study on the re-employment process of career-interrupted women, Dongshin University, Doctoral Dissertation, (2013)

[21] H. H. Kim, Structural relationship analysis among junior college students' perceived social support, career decision level, career decision self-efficacy, and career preparation behavior, Dong-A University, Doctoral Dissertation, (2017)

[22] J. T. Austin, Book Review: Career choice and development, 2nd ed., Journal of Behavioral Decision Making, (1994), Vol.7, No.3, pp.214-216, DOI: https://doi.org/10.1002/bdm.3960070307

[23] J. C. Yoon, S. H. Han, M. S. Park, Effects of Adults' Participation Motives for Lifelong learning, and their Satisfaction 
and Learning Outcomes on Social Capital Formation, Journal of the Korea Academia-Industrial cooperation Society, (2016), Vol.17, No,2, pp.579-589, DOI: http://dx.doi.org/10.5762/KAIS.2016.17.2.579

[24] B. D. Ruben, Quality in Higher Education, Transaction Publishers, (1995)

[25] K. H. Seo, W. J. Kwak, J. H. Shim, The Influence of Career-Interrupted Women's Career Decision-Making SelfEfficacy on Career Adaptability, Journal of Employment and Career, (2015), Vol.5, No.4, pp.57-88, DOI : 10.35273/jec.2015.5.4.003

[26] G. Y. Jang, Development of a career adaptability scale for college students, Sookmyung Women's University, Doctoral Dissertation, (2009)

[27] S. Y. Lim, A Study on the Building Social Capital of the Excellent Community Centers in Seoul, Department of Urban Administration Graduate School of University of Seoul, (2002)

[28] S. H. Osipow, Theories of Career Development, Prentice, (1973)

[29] W. J. A. VandenHeuvel, P. G. Wislocki, M. P. Hirsch, N. K. Porter, R. T. Ambrose, K. A. Robillard, Bioconcentration and Metabolism of Thiabendazole in Bluegill Sunfish, Lepomis macrochirus, Journal of agricultural and food chemistry, (1997), Vol.45, No.3, pp.985-989, DOI: https://doi.org/10.1021/jf9602333

[30] S. M. Yang, C. M. Han, J. N. Yang, Factors Affecting Educational Satisfaction of NONG-HYUP Multicultural Women's University and Policy Implications, Korean Journal of Sociology, Sociology Competition Collection, (2009), Vol.1, pp.611-623.

[31] M. J. Kim, A study on midlife sense of crisis and its related variables, Ewha Womans University, Doctoral Dissertation, (1989)

[32] N. E. Betz, Implications of the null environment hypothesis for women's career development and for counseling psychology, The Counseling Psychologist, (1989), Vol.17, No.1, pp.136-144. DOI: https://doi.org/10.1177/ 0011000089171008

[33] S. K. Lee, Y. S. Na, A Study on the Effect of NCS(National Competency Standards) on the Operation of Vocational Training Course, Journal of Corporate Education and Talent Research, (2000), Vol.19, No.2, pp.57-80.

[34] Y. D. Lee, G. B. Jung, A study on the direction of lifelong vocational education based on the National Competency Standards (NCS), Journal of Employment and Career, (2018), Vol.8, No.2, pp.97-115, DOI: DOI : 10.35273/jec.2018.8.2.005

[35] G. Y. Nam, J. S. Yoon, G. H. Lim, The Effects of Learners' Job Competency Development on the Improvement of Their Vocational Key Competencies in Lifelong Education Based on National Competency Standards(NCS), Journal of Korea Academia-Industrial cooperation Society, (2017), Vol.18, No.2, pp.130-141.

[36] P. J. Rottinghaus, S. X. Day, F. H. Borgen, The Career Future Inventory: A measure of career-related adaptability and optimism, Journal of Career Assessment, (2005), Vol.13, No.1, pp.3-24, DOI: https://doi.org/10.1177/1069072704270271

[37] E. J. Joe, K. H. Lee, Effects of social support programs for adult learners on career adaptability, The Korean Journal of Human Resource Development Quarterly, (2015), Vol.17, No.4, pp.77-104, DOI: 10.18211/kjhrdq.2015.17.4.004 